\title{
Research on Practice Teaching Strategy of Accounting Information System Based on Competency Model
}

\author{
Suli Hao * \\ School of Management \\ China University of Mining and Technology, Beijing \\ Beijing, China \\ sluckylh@126.com
}

\author{
Tian Gao \\ School of Management \\ China University of Mining and Technology, Beijing \\ Beijing, China \\ gaotianlunlun@163.com
}

\author{
Qinghua Hao \\ Education and Sports Bureau of Jize County \\ Hebei Province, China
}

\begin{abstract}
Practical ability is the key to the student integration into their work. Practical teaching is one of the extremely important processes in undergraduate teaching and an integral part of the whole teaching content and curriculum system. This paper comprehensively uses the iceberg model and competency model to construct the influencing factors system of accounting information system practice teaching based on the undergraduate practice teaching research. In addition, this paper determines the key factors affecting the practice teaching of accounting information system through questionnaire survey methods and proposes targeted suggestions to improve the quality of practical teaching of accounting information systems.
\end{abstract}

Keywords - competency model; accounting information system; practical teaching; influence factor; triangular fuzzy number

\section{INTRODUCTION}

The undergraduate education of China has long paid great attention to knowledge transfer and lack of training in students' practical ability. This leads to poor initiative and initiative of students. Improving the overall quality of college students is an important part of ensuring the quality of higher education. The comprehensive quality of students is reflected in many aspects such as the analysis and solving ability of practical problems. In addition, society and schools are constantly creating conditions to strengthen the cultivation of students' comprehensive quality. Therefore, the purpose, conscious and strategic training of college students' practical ability have become an increasingly important topic and a hot spot of concern.

Researchers in Europe and the United States have been studying the issue of practical education since the middle of the last century. They have long recognized the importance of practical education and very focused on guiding students to develop the ability to solve practical problems. In 1978, the "Practical Education" written by American scholar Mary Aiguwosi gave several definitions, such as entertainment, conversation, reading, and geographic exploration. Students can develop through these practical activities which show that the United States Education scholars have long considered and explored practical education issues. Since the 1990s, the new curriculum standard movement in the United States has been widely developed and many national curriculum standards have been born. Affected by the new curriculum standards, best classroom practices are popular in schools. The Massachusetts Institute of Technology has established a systematic and practical education system, which includes a series of practical activities including undergraduate research activities, extracurricular academic activities and undergraduate independent research activities. This will enable students to combine knowledge learning, ability development and personality development. Western countries not only focus on academic discussion, but also attach great importance to practical education for students.

In the 1980s in China, practical education began to enter people's field of vision as a research field. Shi Jingwei of Tsinghua University explored the multiple meanings of practical education for learners. Yang Huanhuan of Wuhan University also discussed the value of social practice education to learners. Yang Wei believes that practical education methods are an important way for socialist talents to be cultivated and cultivated. Teacher Li Zai believes that the fundamental entry point for practical education is to promote development through practice. In practice teaching and reflection, $\mathrm{Yu}$ Huiying from the Central Institute of Educational Science believes that the development of modern brain science has brought new understanding to people, that is, practical activities should emphasize the combination of "hands-on operation" and "brain thinking". However, there are several obvious problems in current practice education: the resources of practical education are not rich enough, and the research on practical education lacks Systematic and lacks sufficient teachers to carry out practical education.[1] Based on the theory of competency, this paper takes accounting computerization as the research object, analyzes the 
influencing factors of accounting computerized practice teaching, and then analyzes the key influencing factors of practical teaching by using the method of triangular fuzzy numbers. Improve specific recommendations for practical teaching.

\section{ANALYSIS OF INFLUENCING FACTORS OF} ACCOUnTING COMPUTERIZATION PRACTICE TEACHING BASED ON COMPETENCY MODEL

\section{A. Analysis of competency characteristics under the iceberg model}

1) Classification of teaching objectives

American Educational Psychologist Benjamin Bloom and $\mathrm{D} \cdot \mathrm{R} \cdot$ Krathwohl according to the individual's cognitive process, from simple to complex, from concrete to abstract, the educational goals are divided into cognitive domains, the Affective Domain, and the Psychomotor Domain form the educational goal system. Details as follows:

- The educational goals in the cognitive field are knowledge, comprehension, application, analysis, synthesis, and evaluation.

- The teaching objectives in the emotional field are divided into five levels: acceptance or attention, response, evaluation or value, organization, value and value system.

- The teaching objectives in the field of motor skills are divided into reflective movements, basic movements, perceptual abilities, physiological abilities, skill movements, and intentional activities.

Bloom's teaching goal classification theory divides each target field into many different levels and levels based on the principles from low-level to high-level, from simple to complex, and cultivating strategies for defining teaching objectives and building students' practical teaching ability.
Instructive significance, in summary, several viewpoints in the classification theory of teaching objectives provide relevant theoretical support and basis for the division of the practical ability dimension in this study.

\section{2) Competency Model}

Professor David McClelland of Harvard University in the United States proposed the concept of "Competency" in the early 1970s. Competency model refers to a combination of capabilities or qualities that an individual should have in order to solve a problem or achieve a certain goal in the face of a specific task. It includes subjective motivation, knowledge and skills, self-image and social role characteristics. The details are shown in Table I:

3) Competency characteristics under the iceberg model

The iceberg model was a famous model developed by the famous American psychologist McClelland in 1973. The iceberg model divides the different expressions of individual quality into the surface of the "above iceberg" and the deep "below of the iceberg". The competency characteristics of the iceberg model theory can be explained in two aspects: on the one hand, the surface features, that is, the content of the iceberg above the water surface. This part of the feature can be objectively observed and evaluated, including conceptual knowledge, professional skills and behavioral practices. On the other hand, it is a deep feature, that is, the content of the iceberg below the surface of the water. This part of the characteristics is relatively stable, including individual cognition, values, personal image, social role and internal drive, etc. Development is relatively difficult, but they are a core component of individual personality and play a key role in individual behavioral activities and behavioral performance. As shown in Fig. 1 below.

TABLE I. COMPETENCY MODEL COMPONENTS

\begin{tabular}{c|l|l}
\hline Component & \multicolumn{1}{c}{ Overview } & \multicolumn{1}{c}{ Effect } \\
\hline Motivation & $\begin{array}{l}\text { It is the subjective motivation to act when individuals are engaged in a } \\
\text { practical activity to achieve a certain purpose. }\end{array}$ & $\begin{array}{l}\text { Motivation enables the actions taken by individuals to be } \\
\text { consistent with subjective psychology and to move forward } \\
\text { without deviation. }\end{array}$ \\
\hline Quality & $\begin{array}{l}\text { It is a more stable response given by the individual to the situation and } \\
\text { the information received. }\end{array}$ & $\begin{array}{l}\text { The combined motivation can predict the behavior pattern of } \\
\text { the individual without being supervised by the outside world } \\
\text { for a long time. }\end{array}$ \\
\hline $\begin{array}{c}\text { Attitude, values } \\
\text { and self-image }\end{array}$ & It is an objective reflection of the individual's self-cognition. & $\begin{array}{l}\text { The combined motivation can predict the working state of the } \\
\text { individual in a short period of time under external } \\
\text { supervision. }\end{array}$ \\
\hline Cial role & $\begin{array}{l}\text { It is an individual's way of doing things and acting style based on self- } \\
\text { cognition in the social environment. }\end{array}$ & $\begin{array}{l}\text { Social roles can internalize the value of individual learned } \\
\text { behavior. }\end{array}$ \\
\hline Knowledge & $\begin{array}{l}\text { It is factual and empirical information that has been verified in an area } \\
\text { owned by an individual. }\end{array}$ & $\begin{array}{l}\text { It is a prerequisite for the application and implementation of } \\
\text { individual skills. }\end{array}$ \\
\hline Mental skills & $\begin{array}{l}\text { Also known as intellectual skills, it is the ability to use structured } \\
\text { knowledge to achieve certain goals. It can be divided into general mental } \\
\text { skills and special mental skills. }\end{array}$ & $\begin{array}{l}\text { Structured work ability can effectively improve the } \\
\text { performance of individuals. }\end{array}$ \\
\hline
\end{tabular}




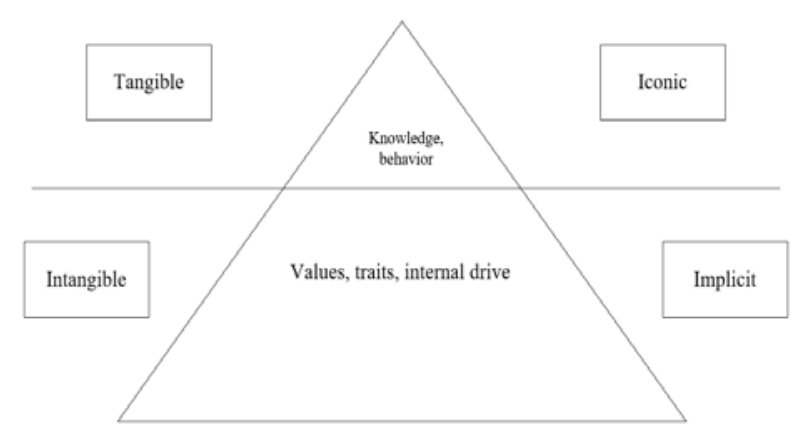

Fig. 1. Competency characteristics under the iceberg model

\section{B. Accounting Computerization Practice Teaching Influencing Factors Dimensions}

According to the previous section, competency exists in five areas: knowledge and skills, social roles, self-image, personality, and motivation. Among them, social roles and self-images are self-recognition/consciousness, and individuality and motivation are personal characteristics. This part of the content is expressed as the individual's inherent behavioral traits and attitude beliefs, which are implicit and difficult to measure. Knowledge and skills are expressed as individual cultural reserves and behavioral performance. From the perspective of talent cultivation, it is not difficult to find that knowledge, skills and personal traits (consciousness, motivation) together constitute a competency model, so the model shown in Fig. 1 above can be improved, as shown in Fig. 2.

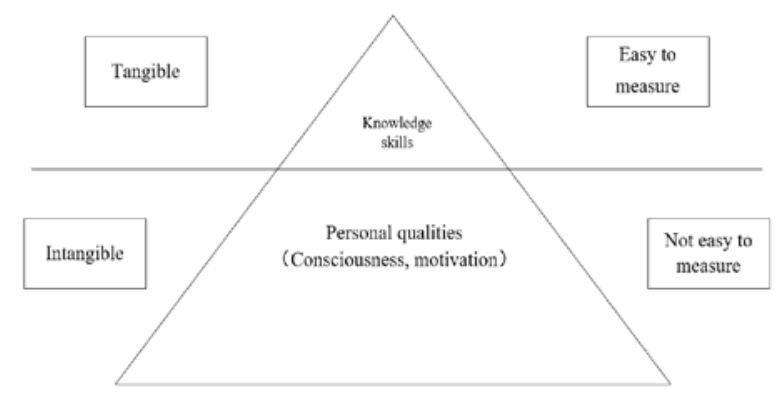

Fig. 2. Improved model

From the perspective of cultivating talents in colleges and universities, competency is the basis for determining whether an individual can meet the requirements of a certain job in the future. It is an important individual characteristic that can determine and influence future performance, and has its own unique characteristics.[2]The improved model can play a supporting and inspiring role for this research.

According to the undergraduate's diversified and multilevel training objectives and requirements, starting from the research of students' main body, combining the feedback information with the actual conditions of current colleges and universities, paying attention to the multi-fact development of students' practical ability, on the basis of a large amount of literature research, Based on the comprehensive analysis of previous research results and supported by the competency model, this study divides the influencing factors of students' practical ability into three dimensions. The dimensions of practical ability are consciousness (motivation) dimension, knowledge dimension and skill (Application) dimension, as shown in Fig. 3:

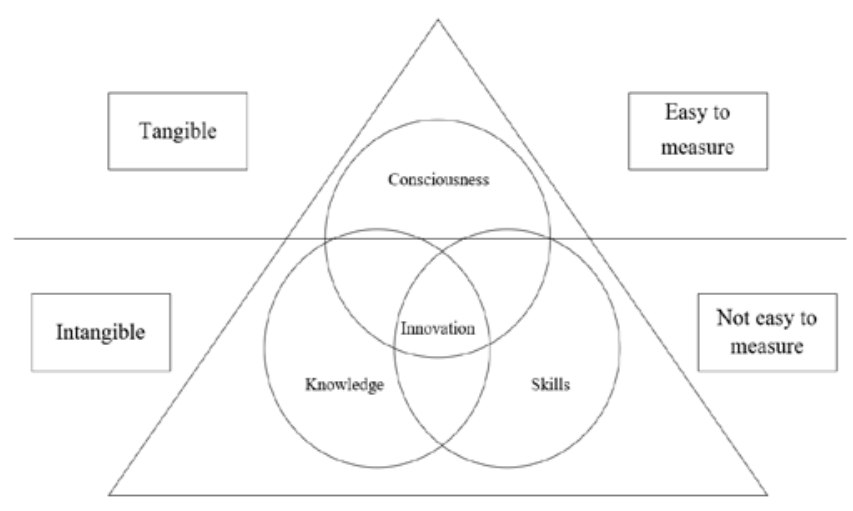

Fig. 3. Practical ability dimension model

There are close links between these three dimensions. The factors of the consciousness dimension affect the students' learning of professional knowledge, and also influence the students' behavioral activities through the influence of consciousness, thus having an indirect influence on the application of students' professional skills. [3] Through the interaction of these three dimensions, we can truly realize the cultivation and promotion of students' creative creativity.

The consciousness dimension, knowledge dimension and skill dimension in this study are elaborated from the three aspects of students' learning motivation, professional knowledge and behavioral activities.

\section{1) Consciousness dimension}

Consciousness is interpreted in dialectical materialism as: the reflection of the human mind on the objective material world, and the sum of various psychological processes such as feelings and thoughts. In the existing research and competency models, the importance of motivation, interest, attitude, etc. Practical ability is mentioned. Therefore, this study proposes the consciousness dimension of practical ability. The connotation of the dimension of practical ability consciousness means that students can consciously absorb practical knowledge, improve their understanding of practice, and consciously develop their own practical ability in daily life. The dimensions of the practical competence awareness mentioned in this study include:

- Personal attitudes and values: including individual students' interest in professional learning and knowledge of knowledge value, it plays an incentive and guidance role for individual practice, and is emotional support for the development of students' practical ability.

- Professional understanding: It is reflected in the students' awareness of the profession, including the understanding of professional characteristics and 
TABLE II. INFLUENCING FACTORS OF ACCOUNTING COMPUTERIZATION PRACTICE TEACHING training programs, and clear professional learning objectives.

- Practical behavioral motives: including individual learning needs and individual learning expectations, is an internal motivation that directly promotes students' practical activities, triggers, maintains, and directs students' practical behaviors to specific purposes. In the daily learning process, whether the students have the awareness of autonomous behavior in the learning process, whether they can actively participate in various practical activities and professional innovation activities inside and outside the school.

\section{2) Knowledge dimension}

The mastery of knowledge directly affects the proficiency of students' application of various professional skills, and the knowledge model also refers to knowledge. The application of skills needs to be supported by theoretical knowledge. The mastery of basic knowledge is directly related to the development of students' practical ability. Therefore, the second dimension of the division of professional practice ability in this study is the knowledge dimension, which is the various dimensions of the ability to practice play a role in theoretical support. The improvement of the practical ability of undergraduates is inseparable from the support of theoretical knowledge. Only by acquiring solid professional knowledge and using the knowledge learned to solve real problems can professional knowledge be turned into professional skills. Therefore, the knowledge dimension of practical ability is a very important dimension.[4] It not only requires students having a simple understanding of knowledge, but also a mastery of fragmentation, but requires students having a complete grasp of the professional knowledge of educational technology.

\section{3) Skill dimension}

Skills refer to the use of concepts, rules, principles, and the ability to master specialized skills. The skill dimension means that students can use the theoretical knowledge and methods and skills they have learned to deal with and solve practical problems, that is, the application level of knowledge.[5] The cultivation of skill dimensions is not only reflected in the daily professional skills training of students, but also in the cultivation of students' scientific research and innovation ability. The skill dimension of practical ability mainly includes the following contents: 1) application of theoretical knowledge; 2) application of multimedia teaching environment and processing of materials; 3) application of teaching media resources and network teaching resources; 4) participation of practical innovation activities.[6]

\begin{tabular}{|c|c|}
\hline Dimension & Factor \\
\hline \multirow{3}{*}{$\begin{array}{l}\text { Consciousness } \\
\text { dimension(C) }\end{array}$} & Course understanding(C11) \\
\hline & Practical behavioral motive(C12) \\
\hline & Interactive communication awareness(C13) \\
\hline \multirow{4}{*}{$\begin{array}{c}\text { Knowledge } \\
\text { dimension(C) }\end{array}$} & Course basics(C21) \\
\hline & Course practice knowledge(C22) \\
\hline & Autonomous learning ability(C23) \\
\hline & Self-evaluation and reflection ability(C24) \\
\hline \multirow{3}{*}{$\begin{array}{c}\text { Skill } \\
\text { dimension } \\
\text { (C3) }\end{array}$} & Knowledge application skills(C31) \\
\hline & Solve practical problem skills(C32) \\
\hline & Resource application skills(C33) \\
\hline
\end{tabular}

\section{Analysis of the impact indicators of accounting} computerization practice teaching

Based on the above dimension analysis of the factors of accounting computerized practice teaching, further, refine, consolidate and summarize the various factors, and propose two levels, three dimensions, ten secondary elements of undergraduate accounting practice teaching impact indicator system, such as Table II shows.

\section{ANALYSIS OF KEY INFLUENCING FACTORS OF ACCOUNTING COMPUTERIZATION PRACTICE TEACHING BASED ON TRIANGULAR FUZZY NUMBERS}

On the basis of the analysis of the influencing factors of accounting computerized practice teaching, from the perspectives of students and teachers, the questionnaire survey and expert scoring method are used to determine the importance degree of each influencing factor and to provide suggestions for improving the quality of accounting computerized practice teaching.[7]

\section{A. Analysis of the influencing factors of practical teaching from the perspective of students}

The analysis of the factors in the quality of practical method of questionnaire survey. This paper uses the method of five-gram special service scale to design the questionnaire, and conducts a questionnaire survey on the undergraduates of five universities in Beijing. 280 copies were collected and 264 copies were collected. The questionnaire recovery rate was $94.2 \%$, including 261 valid questionnaires. The effective rate of the questionnaire was $98.9 \%$, which was in line with the research standards. Therefore, the results of this questionnaire are valid.

\section{1) Questionnaire statistics}

The main subjects of the questionnaire are junior and senior students, because the lower grade students mainly focus on basic theory courses, less practical courses, and insufficient understanding of practical courses. The specific grade distribution is shown in Fig. 4. teaching from the perspective of students mainly adopts the 


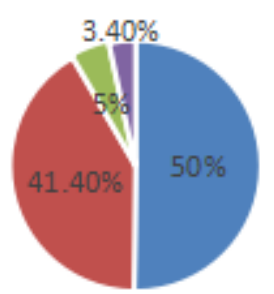

- Junior - Senior - Sophomore Ereshman

Fig. 4. Grade distribution

2) Analysis of key influencing factors of practical teaching

The data analysis of the questionnaire mainly adopts the fuzzy performance theory method. According to the theory and steps of fuzzy performance, the results of the questionnaire involving the likers scale (a total of 12 questions, involving 52 indicators) are constructed. Second, the scores of all the questionnaires are counted. The sum of all the five-level indicators in the questionnaire that selects an option of a certain question is summed, and this sum represents the respondent's attitude toward the option. Then, divide the total number of statistics in the previous step by the total number of questionnaires, and get the membership degree of an option in a question. This value represents the attitude of the respondent to the degree of the option, that is, the weight of the option. ". Finally, the level 5 indicators for each option are assigned 1 point, 2 points, 3 points, 4 points, and 5 points in order from low to high. On the basis of the assignment, multiplying the membership value of each option by the assigned score, the statistical result of the 5point system of the Liker scale is obtained, that is, the comprehensive score. As shown in Fig. 5.

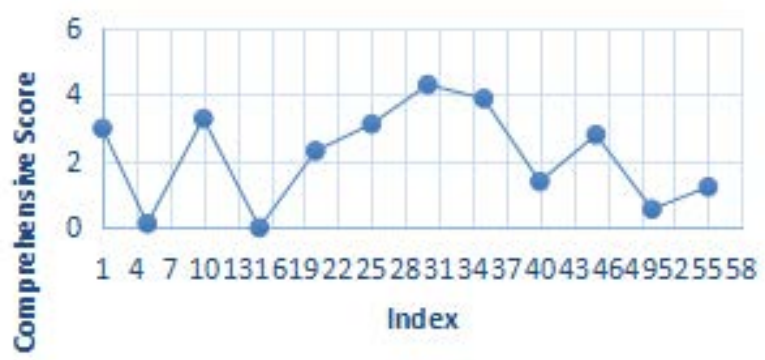

Fig. 5. Comprehensive score chart of each indicator

\section{B. Analysis of key influencing factors of practical teaching from the perspective of teachers}

\section{1) Triangular fuzzy number model}

The triangular fuzzy number $\mathrm{M}$ on the domain $\mathrm{R}$ is often expressed as $(l, m, u), l \leq m \leq u$, $\mathrm{m}$ is the median of the membership degree of $\mathrm{M}$, and $\mathrm{l}$ and $\mathrm{u}$ represent the lower and upper bounds of $\mathrm{M}$, respectively. That is, the parameters $\mathrm{l}, \mathrm{m}$, $\mathrm{u}$ represent the minimum possible value, the most probable value and the maximum possible value of the degree of blurring, respectively.[8] The membership function of $\mathrm{M}$ is

$$
\mathrm{u}_{M}(x)=\left\{\begin{array}{l}
\frac{x-1}{m-1}, 1 \leq x \leq m \\
\frac{u-x}{u-m}, m \leq x \leq u \\
0, \text { others }
\end{array}\right.
$$

Where $\mathrm{x}$ is $\mathrm{m}, \mathrm{x}$ is completely $\mathrm{M}$, and none other than $\mathrm{l}$, $\mathrm{u}$ is not a fuzzy number $\mathrm{M}$. The operational properties of triangular fuzzy numbers:

$$
\begin{aligned}
& \mathrm{a}=\left(a_{l}, a_{\mathrm{m}}, a_{u}\right) \mathrm{b}=\left(b_{l}, b_{m}, b_{u}\right) \\
& a+b=\left(a_{l}+b_{l}, a_{m}+b_{m}, a_{u}+b_{u}\right) ; \\
& a \times b=\left(a_{l} b_{l}, a_{m} b_{m}, a_{u} b_{u}\right) ; \\
& \lambda \times a=\left(\lambda a_{l}, \lambda a_{m}, \lambda a_{u}\right) ;
\end{aligned}
$$

2) Analysis of key influencing factors of practical teaching based on triangular fuzzy numbers

In this paper, the method of triangular fuzzy numbers is used to investigate the teachers of 20 practical teachings, so that they can score the triangular fuzzy judgment matrix of the influencing factors of practical teaching. Here, taking the first dimension as an example, analyze the importance of each indicator. The specific steps are as follows:

Step 1: Determine the evaluation factor set $\mathrm{U}$.

Take the first-level indicator as an example, $U=C 1+C 2+C 3$

Step 2: Record the set of triangular fuzzy number complementary judgment matrices obtained by m experts using the triangular fuzzy number pairwise comparison of the indicators according to the 0.1-0.9 scale:

$$
\begin{aligned}
& A_{k}=\left(a_{i j}{ }^{k}\right)_{n \times n}=\left(l_{i j}{ }^{k}, m_{i j}{ }^{k}, u_{i j}{ }^{k}\right)_{n \times n,} k=1,2 \ldots m, i, j=1,2 \ldots n, \\
& \mathrm{a}_{i j}{ }^{k}=\left(l_{i j}{ }^{k}, m_{i j}{ }^{k}, u_{i j}{ }^{k}\right)
\end{aligned}
$$

It represents the triangular fuzzy number of the kth expert comparing the importance of indicator $i$ and index $j$.

Step 3: Set the weight of the experts to use the weighting method to assemble the evaluations of the experts.

$$
A_{k}=\left(a_{i j}{ }^{k}\right)_{n \times n}=\left(l_{i j}{ }^{k}, m_{i j}{ }^{k}, u_{i j}{ }^{k}\right)_{n \times n}, k=1,2 \ldots m, i, j=1,2 \ldots n,
$$$$
=\mathrm{k}_{1} \otimes A^{1} \oplus k_{2} \otimes A^{2} \oplus \ldots \oplus k_{m} \otimes A^{m}
$$

$\mathrm{k}_{1}+k_{2}+\ldots k_{m}=1$ 
TABLE III. WEIGHTED TRIANGULAR FUZZY NUMBER COMPLEMENTARY JUDGMENT MATRIX

\begin{tabular}{c|c|c|c|c}
\hline \multicolumn{2}{c|}{$\begin{array}{c}\text { Weighted triangular } \\
\text { fuzzy number } \\
\text { complementary } \\
\text { judgment matrix }\end{array}$} & $\mathrm{C} 1$ & $\mathrm{C} 2$ & $\mathrm{C} 3$ \\
\cline { 2 - 5 } & $\mathrm{C} 1$ & $(0.5,0.5,0.5)$ & $(0.14,0.26,0.4)$ & $\begin{array}{c}(0.12,0.26,0.3 \\
8)\end{array}$ \\
\hline \multirow{4}{*}{$\mathrm{A}$} & $\mathrm{C} 2$ & $\begin{array}{c}(0.6,0.74,0.8 \\
6)\end{array}$ & $(0.5,0.5,0.5)$ & $\begin{array}{c}(0.14,0.28,0.4 \\
2)\end{array}$ \\
\cline { 2 - 5 } & $\mathrm{C} 3$ & $\begin{array}{c}(0.62,0.74,0 . \\
88)\end{array}$ & $\begin{array}{c}(0.58,0.72,0.86 \\
)\end{array}$ & $(0.5,0.5,0.5)$ \\
\hline
\end{tabular}

Step 4: Consistency Test of Triangular Fuzzy Complementary Judgment Matrix $A\left(a_{i j}\right)_{n \times n}$

- Here we use an approximate method to judge, and the fuzzy complementary judgment matrix $M=\left(\mathrm{m}_{\mathrm{ij}}\right)_{n \times n}$ obtained by extracting the most likely estimated value $A\left(\mathrm{a}_{i j}\right)$ is recorded as shown in Table IV.

TABLE IV. FUZZY CONSISTENT JUDGMENT MATRIX

\begin{tabular}{c|c|c|c|c|c}
\hline \multirow{2}{*}{$\begin{array}{c}\text { Most likely } \\
\text { estimated value } \\
\text { fuzzy } \\
\text { complementary } \\
\text { judgment }\end{array}$} & \multicolumn{4}{c}{ Evaluation index } \\
\cline { 2 - 6 } & $\mathrm{C} 1$ & $\mathrm{C} 2$ & $\mathrm{C} 3$ & $\mathrm{~m}$ \\
\hline \multirow{2}{*}{$\mathrm{M}$} & $\mathrm{C} 1$ & 0.5 & 0.26 & 0.26 & 1.02 \\
\cline { 2 - 6 } $\mathrm{M}$ & $\mathrm{C} 2$ & 0.74 & 0.5 & 0.28 & 1.52 \\
\cline { 2 - 6 } & $\mathrm{C} 3$ & 0.74 & 0.72 & 0.5 & 1.96 \\
\hline
\end{tabular}

TABLE VI.

WEIGHT SOLVING TABLE

\begin{tabular}{c|c|c|c|c}
\hline & $\left(\sum_{j=1}^{5} l_{i j}, \sum_{j=1}^{5} m_{i j}, \sum_{j=1}^{5} u_{i j}\right)$ & The comprehensive fuzzy evaluation value & Expected value & Weights \\
\hline C1 & $(0.76,1.02,1.28)$ & $(0.21,0.23,0.24)$ & 0.23 & 0.23 \\
\hline C2 & $(1.24,1.52,1.78)$ & $(0.34,0.34,0.34)$ & 0.34 & 0.34 \\
\hline C3 & $(1.7,1.96,2.24)$ & $(0.46,0.44,0.42)$ & 0.43 & 0.43 \\
\hline
\end{tabular}

TABLE VII. ANALYSIS OF THE IMPORTANCE OF THE FACTORS INFLUENCING THE QUALITY OF PRACTICAL TEACHING

\begin{tabular}{|c|c|c|c|c|c|}
\hline Target layer & $\begin{array}{c}\text { First-level indicator } \\
\text { weight }\end{array}$ & Secondary indicator weight & $\begin{array}{c}\text { Teacher perspective } \\
\text { importance }\end{array}$ & $\begin{array}{c}\text { Student perspective } \\
\text { importance }\end{array}$ & $\begin{array}{c}\text { The importance of } \\
\text { each factor }\end{array}$ \\
\hline \multirow{10}{*}{$\begin{array}{l}\text { Influential factors of } \\
\text { practical teaching }\end{array}$} & \multirow{3}{*}{$\begin{array}{l}\text { Consciousness } \\
\text { indicator } \\
\text { C1(0.23) }\end{array}$} & $\begin{array}{c}\text { Course understanding } \\
\text { C11(0.31) }\end{array}$ & 0.0713 & 1.63 & 0.116 \\
\hline & & $\begin{array}{c}\text { Practical behavioral motive } \\
\text { C12(0.43) } \\
\end{array}$ & 0.0989 & 1.77 & 0.175 \\
\hline & & $\begin{array}{l}\text { Interactive communication } \\
\text { awareness C13(0.26) }\end{array}$ & 0.0598 & 2.04 & 0.122 \\
\hline & \multirow{4}{*}{$\begin{array}{l}\text { Knowledge indicator } \\
\text { C2(0.34) }\end{array}$} & Course basicsC21(0.18) & 0.0612 & 1.88 & 0.115 \\
\hline & & $\begin{array}{c}\text { course practice knowledge } \\
\text { C22(0.33) }\end{array}$ & 0.1122 & 2.73 & 0.306 \\
\hline & & $\begin{array}{c}\text { Autonomous learning ability } \\
\text { C23(0.23) }\end{array}$ & 0.0782 & 1.57 & 0.123 \\
\hline & & $\begin{array}{c}\text { Independent evaluation and } \\
\text { reflectionC24(0.26) }\end{array}$ & 0.0884 & 3.18 & 0.281 \\
\hline & \multirow{3}{*}{$\begin{array}{l}\text { Skill indicator } \\
\text { C3(0.43) }\end{array}$} & $\begin{array}{c}\text { Knowledge application skills } \\
\text { C31(0.32) } \\
\end{array}$ & 0.1376 & 2.35 & 0.323 \\
\hline & & $\begin{array}{c}\text { Solve the real problem } \\
\text { C32(0.43) }\end{array}$ & 0.1849 & 3.34 & 0.618 \\
\hline & & $\begin{array}{c}\text { Resource application skills } \\
\text { C33(0.25) }\end{array}$ & 0.1075 & 1.84 & 0.198 \\
\hline
\end{tabular}


and outside the school, and carry out various forms of innovative practical skills competitions in combination with professional characteristics.

\section{REFERENCES}

[1] Zeng Sulin. On Practical Education-Based on Empirical Analysis and International Comparison [D]. Central China Normal University, 2013.

[2] Liao Guojiang. Research on the evaluation method of the full-time engineering master's practical ability [D]. South China University of Technology, 2014.

[3] Huang Danyan. Research on the cultivation of scientific research ability of undergraduates in Chinese research universities [D]. Central South University, 2009.

[4] Hu Yonghong. The application of undergraduate practice teaching system and its connection with postgraduate training mode [J]. Higher Education in Chemical Engineering, 2018 (01): 57-61.

[5] Xing Jinyu. Analysis of the cultivation of undergraduates' practical ability. [J]. China University Science and Technology, 2013 (01-02): 7475.

[6] Sun Jinya. Exploring the practical teaching system of college students in "zero adaptation period”. [J]. Management Observation, 2017, (01): 135-137.

[7] Sun Wei. Reconstruction of the practical teaching system of undergraduate students in management. [J]. Chinese University Teaching, 2005, (06): 44-45.

[8] Si Shubin's weight analysis of comprehensive support evaluation index based on triangular fuzzy numbers. [J]. Journal of Northwestern Polytechnical University, 2004, (06): 690-694.

[9] Liu Ximei. Research on Teaching Quality Evaluation Based on Triangular Fuzzy Analytic Hierarchy Process[J]. Journal of Chongqing Technology and Business University, 2013, (08): 46-49. developing students' ability to use the knowledge they have learned to deal with problems.In addition, the school should also encourage students to actively participate in the practice activities in the form of professional skills competitions inside 